\title{
Preparation of nitrogen-doped carbon nanoblocks with high electrocatalytic activity for oxygen reduction reaction in alkaline solution
}

\author{
Tingting Zhang, Chuansheng He, Linbo Li, Yuqing Lin * \\ Department of Chemistry, Capital Normal University, Beijing 100048, China
}

\section{A R T I C L E I N F O}

Article history:

Received 4 January 2016

Accepted 29 April 2016

Published 5 August 2016

\section{Keywords:}

Nitrogen-doped carbon nanoblock

Trihydroxymethyl aminomethane

Electrocatalyst

Oxygen reduction reaction

Nanocatalyst

\begin{abstract}
A B S T R A C T
The oxygen reduction reaction (ORR) is traditionally performed using noble-metals catalysts, e.g. Pt. However, these metal-based catalysts have the drawbacks of high costs, low selectivity, poor stabilities, and detrimental environmental effects. Here, we describe metal-free nitrogen-doped carbon nanoblocks (NCNBs) with high nitrogen contents (4.11\%), which have good electrocatalytic properties for ORRs. This material was fabricated using a scalable, one-step process involving the pyrolysis of tris(hydroxymethyl)aminomethane (Tris) at $800^{\circ} \mathrm{C}$. Rotating ring disk electrode measurements show that the NCNBs give a high electrocatalytic performance and have good stability in ORRs. The onset potential of the catalyst for the ORR is $-0.05 \mathrm{~V}$ ( $\mathrm{vs} \mathrm{Ag} / \mathrm{AgCl}$ ), the ORR reduction peak potential is $-0.20 \mathrm{~V}$ ( $\mathrm{vs} \mathrm{Ag} / \mathrm{AgCl})$, and the electron transfer number is 3.4. The NCNBs showed pronounced electrocatalytic activity, improved long-term stability, and better tolerance of the methanol crossover effect compared with a commercial $20 \mathrm{wt} \% \mathrm{Pt} / \mathrm{C}$ catalyst. The composition and structure of, and nitrogen species in, the NCNBs were investigated using Fourier-transform infrared spectroscopy, scanning electron microscopy, X-ray photoelectron spectroscopy, and X-ray diffraction. The pyrolysis of Tris at high temperature increases the number of active nitrogen sites, especially pyridinic nitrogen, which creates a net positive charge on adjacent carbon atoms, and the high positive charge promotes oxygen adsorption and reduction. The results show that NCNBs prepared by pyrolysis of Tris as nitrogen and carbon sources are a promising ORR catalyst for fuel cells.
\end{abstract}

(C) 2016, Dalian Institute of Chemical Physics, Chinese Academy of Sciences. Published by Elsevier B.V. All rights reserved.

\section{Introduction}

Fuel cells are highly promising energy conversion devices because they are renewable and have low emissions and high efficiencies. The oxygen reduction reaction (ORR) significantly affects the cathode performance in fuel cells, and efficient ORR electrocatalysts are necessary for practical applications of fuel cells [1-5]. The main products of the ORR are $\mathrm{OH}^{-}$and $\mathrm{HO}_{2}^{-}$, and are determined by the major component of the electrode material, electrode potential, and electrolyte [6-8]. Pt and its alloys are currently regarded as the best catalysts for the ORR $[9,10]$. However, the limited reserves of Pt, high cost, activity deterioration with time, and poor durability severely hinder large-scale use of Pt in ORRs [11-13]. The development of nonprecious-metal and Pt-free catalysts for fuel cells is therefore important [14-18].

\footnotetext{
* Corresponding author. Tel/Fax: +86-10-68903047; E-mail: linyuqing@cnu.edu.cn

This work was supported by the National Natural Science Foundation of China (21375088, 21575090), Scientific Research Project of Beijing Educational Committee (KM201410028006), Youth Talent Project of the Beijing Municipal Commission of Education (CIT\&TCD201504072), and Scientific Research Base Development Program of the Beijing Municipal Commission of Education. 
Carbon materials have many advantages such as excellent catalytic activity, low costs, long-term stability, and good tolerance of the methanol crossover effect [19-21]. Carbon materials for use in the ORR as alternatives to Pt-based catalysts have therefore attracted enormous interest. It was recently reported that nitrogen-doped carbon materials show excellent ORR electrocatalytic activity because of their unique electronic properties derived from conjugation between nitrogen lone-pair electrons and the graphene system, i.e., nitrogen doping can improve the electron-donor properties, improving interactions between carbon and oxygen molecules to create metal-like conductivity [22-25]. Dai's group [26] used chemical vapor deposition to produce a nitrogen-doped graphene (NG) that showed better ORR catalytic activity than Pt in alkaline fuel cells. They also developed nitrogen-doped carbon nanotube arrays that showed better electrocatalytic activity, long-term operational stability, and tolerance to the methanol effect than did Pt in oxygen reduction in alkaline fuel cells [27]. Shen's group [28] prepared an ORR catalyst consisting of nitrogen-doped porous carbon particles with a high proportion of pyridinic nitrogen atoms using a combination of the Maillard reaction and thermal annealing in an $\mathrm{NH}_{3}$ atmosphere. Xian's group [29] synthesized a non-precious-metal oxygen electrode electrocatalyst consisting of $\mathrm{MoS}_{2} / \mathrm{NG}$ by physically mixing $\mathrm{MoS}_{2}$ sheets with NG; the catalyst showed improved electrocatalytic activity in the ORR based on a four-electron pathway in alkaline solutions.

Different preparation conditions can change the structural properties of material such as the specific surface area, electronic conductivity, doping content, and doping state, and these significantly affect the ORR electrocatalytic performance of nitrogen-doped carbon materials. Various direct synthetic methods such as spray pyrolysis, chemical vapor deposition, and solvothermal reactions are effective for preparing nitrogen-doped carbon materials, but high costs, low yields, and complicated processes make these methods unsatisfactory [30-32]. Despite much effort using various synthetic methods, the development of cheap, efficient, and simple methods for the production of nitrogen-doped nanocarbons with excellent catalytic performance in ORRs is still a challenge [33-36].

In this study, we developed an improved approach based on direct one-step pyrolysis for preparing nitrogen-doped carbon nanoblocks (NCNBs) with high nitrogen contents (4.11\%). We used tris(hydroxymethyl)aminomethane (Tris) as the carbon and nitrogen sources because it is a cheap and readily available small molecule containing hydroxyl and amino groups. The NCNBs obtained by pyrolysis below $800{ }^{\circ} \mathrm{C}$ had diameters of approximately $60 \mathrm{~nm}$ and gave a good catalytic performance in the ORR. This can be ascribed to the electron-accepting ability of the nitrogen atoms resulting in creation of net positive charges on adjacent carbon atoms, and these readily attract electrons. The morphology of the prepared NCNBs was studied using scanning electron microscopy (SEM). X-ray photoelectron spectroscopy (XPS) was used to identify the surface nitrogen groups. The electrochemical performance of the NCNBs in the ORR was evaluated in detail.

\section{Experimental}

\subsection{Chemicals}

Tris was purchased from Sigma. A saturated solution of Tris was prepared using double-distilled water. A 20\% Pt/C catalyst was purchased from Aladdin. All other chemicals (analytical grade) were purchased from the Beijing Chemical Reagent Company (Beijing, China) and used without further purification. Ultra-pure water was obtained using a Milli-Q plus water purification system (18 MW, Milli-pore Co., Ltd., USA).

\subsection{Apparatus}

SEM images were obtained using a Hitachi S-2600N instrument. Elemental analysis was performed using a Flash EA 1112 instrument. XPS was performed using a VG Micro-tech ESCA 2000 instrument with a monochromatic 15 Al X-ray source. Fourier-transform infrared (FTIR) spectroscopy was performed using an EQUINOX 55 instrument (Bruker, Germany). Electrochemical measurements were performed using a computer-controlled electrochemical analyzer (CHI600E, Chenhua, China) in a two-compartment electrochemical cell with a bare or modified glassy carbon electrode (GCE, diameter $3 \mathrm{~mm}$ ) and a rotating ring disk electrode (RRDE; PINE) of diameter $4 \mathrm{~mm}$ as the working electrode. The geometric area of the RRDE was $0.1256 \mathrm{~cm}^{2}$. Pt wire was used as the counter electrode, and the reference electrode was $\mathrm{Ag} / \mathrm{AgCl}$ (3 mol/L-KCl).

\subsection{NCNB preparation}

A saturated solution of Tris was placed in a quartz-tube reactor and dried overnight at $70^{\circ} \mathrm{C}$. The quartz-tube reactor was transferred to a tube furnace and pyrolyzed in a vacuum at 700 , 800 , or $900{ }^{\circ} \mathrm{C}$ for $2 \mathrm{~h}$, to prepare different NCNBs, denoted by NCNBs-700, NCNBs-800, and NCNBs-900, respectively.

\subsection{Electrochemical characteristics}

A GCE of diameter $3 \mathrm{~mm}$ and geometric area $0.07065 \mathrm{~cm}^{2}$ was used as the working electrode. The GCE was polished with $1.0,0.3$, and $0.05 \mu \mathrm{m}$ alumina slurries, and then washed with ultraclean water and ethanol, respectively, to form a mirror-like surface. NCNBs (6 mg) were ultrasonically dispersed in dimethylformamide (DMF, $1 \mathrm{~mL}$ ). The prepared ink solution (5 $\mu \mathrm{L})$ was dropped onto the GCE. The working electrode was prepared as follows. The NCNB suspension $(5 \mu \mathrm{L}, 6 \mathrm{mg} / \mathrm{mL}$ in DMF) was dropped onto the GCE surface, and exposed to air to evaporate the solvent. The electrode surface was covered with Nafion solution ( $5 \mu \mathrm{L}, 0.5 \%, 5$ diluted 10 times with deionized water) and dried to form a modified working electrode. The electrode was rinsed thoroughly with deionized water to remove physically adsorbed materials to give an NCNBs/GCE. The modified working electrodes were used to study ORR activity.

All electrochemical experiments were performed at room temperature. The NCNBs/GCE was pretreated by electrochem- 
ical oxidation in a phosphate-buffered solution $(\mathrm{pH}=6.8)$ at a potential of $1.7 \mathrm{~V}$ (vs $\mathrm{Ag} / \mathrm{AgCl}$ ) for $300 \mathrm{~s}$ at room temperature, followed by potential sweeping from 0.0 to $1.4 \mathrm{~V}$ in $\mathrm{H}_{2} \mathrm{SO}_{4}(0.5$ $\mathrm{mol} / \mathrm{L}$ ) until a stable voltammogram was obtained. The surface ORR activity of the catalyst in $\mathrm{O}_{2}$-saturated $\mathrm{KOH}(0.1 \mathrm{~mol} / \mathrm{L})$ was investigated by linear sweep voltammetry (LSV) of the NCNBs/GCE from 0.2 to $-1.0 \mathrm{~V}$ at a rate of $10 \mathrm{mV} / \mathrm{s}$. For quantitative measurements of the ORR activity, LSV of the catalyst-coated RRDE at a scan rate of $5 \mathrm{mV} / \mathrm{s}$ in $\mathrm{O}_{2}$-saturated $\mathrm{KOH}$ solution was conducted at various rotation rates from 400 to $2025 \mathrm{r} / \mathrm{min}[37,38]$.

\section{Results and discussion}

\subsection{Investigation of Tris carbonization}

Fig. 1 shows the X-ray diffraction (XRD) patterns of the samples. Pyrolysis significantly changes the Tris diffraction peak. The NCNBs formed at different temperatures all give two broad peaks characteristic of turbostratic carbon. The diffraction peaks of NCNBs-800 are stronger than those of NCNBs-700 and NCNBs-900, indicating a high graphitization degree at this temperature. The NCNBs-800 peak is much narrower than those of the other samples, showing that $800{ }^{\circ} \mathrm{C}$ can promote graphitization of the carbon formed during carbonization.

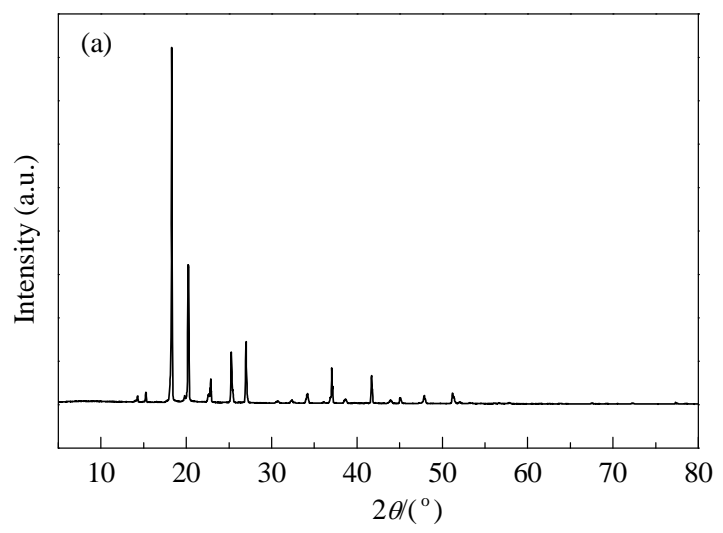

\subsection{Investigation of electrochemical behavior of NCNBs in ORR}

The ORR activities of the NCNBs were investigated by performing $\mathrm{LSV}$ in $\mathrm{N}_{2}$ - and $\mathrm{O}_{2}$-saturated $\mathrm{KOH}$ solution $(0.1 \mathrm{~mol} / \mathrm{L})$. Fig. 2 shows that the ORR reduction peak potentials for the NCNBs-700 and NCNBs-900 are -0.26 and $-0.24 \mathrm{~V}$ (vs $\mathrm{Ag} / \mathrm{AgCl}$ ), respectively. However, the ORR reduction peak potential for the NCNBs-800 is $-0.20 \mathrm{~V}$ (vs $\mathrm{Ag} / \mathrm{AgCl}$ ), i.e., positive shifts of -0.06 and $-0.04 \mathrm{~V}$ compared with those for the NCNBs-700 and NCNBs-900, respectively, occurred; a concomitant increase in the peak current density was observed. These results clearly show significant enhancement of the ORR electrocatalytic activity for NCNBs produced at $800{ }^{\circ} \mathrm{C}$. The high electrocatalytic activity of the NCNBs can be attributed to the electron-accepting ability of the nitrogen atoms, which creates a net positive charge on adjacent carbon atoms in the carbon plane of the NCNBs; electrons are readily attracted from the anode, facilitating the ORR.

\subsection{NCNBs-800 characterization}

Fig. 3(a) shows SEM images of the NCNBs-800. The images obtained at various magnifications show that the NCNBs-800 are distributed uniformly in blocks of diameter about $60 \mathrm{~nm}$. The molecular structure of the NCNBs-800 was investigated

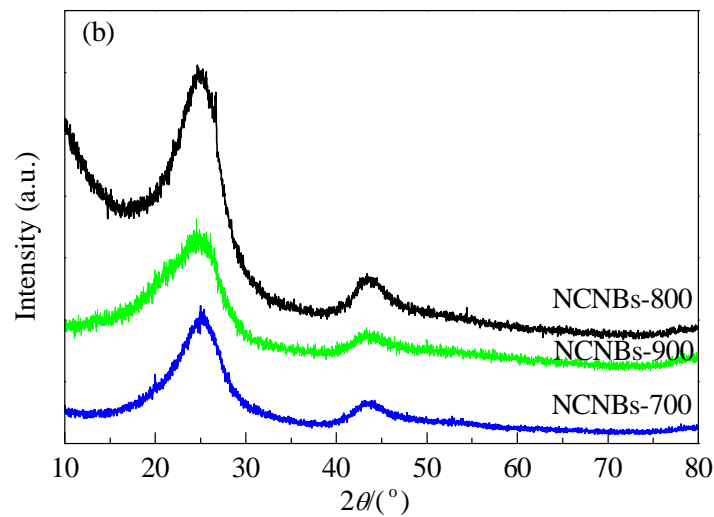

Fig. 1. XRD patterns of (a) Tris and (b) Tris-derived NCNBs at different temperatures.
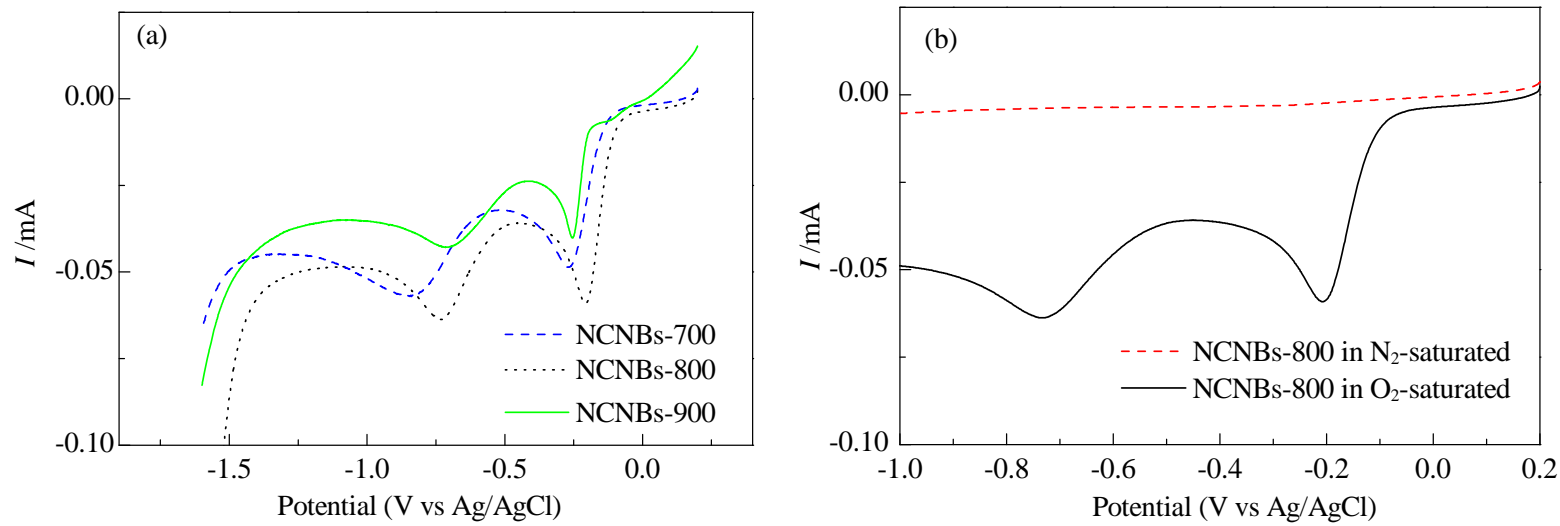

Fig. 2. (a) Linear sweep voltammetry of oxygen reduction on the NCNBs/GC electrodes in an $\mathrm{O}_{2}$-saturated $\mathrm{KOH}(0.1 \mathrm{~mol} / \mathrm{L})$; (b) NCNBs-800/GCE in an $\mathrm{O}_{2}$-saturated and $\mathrm{N}_{2}$-saturated $\mathrm{KOH}(0.1 \mathrm{~mol} / \mathrm{L})$ at a scan rate of $10 \mathrm{mV} / \mathrm{s}$. 


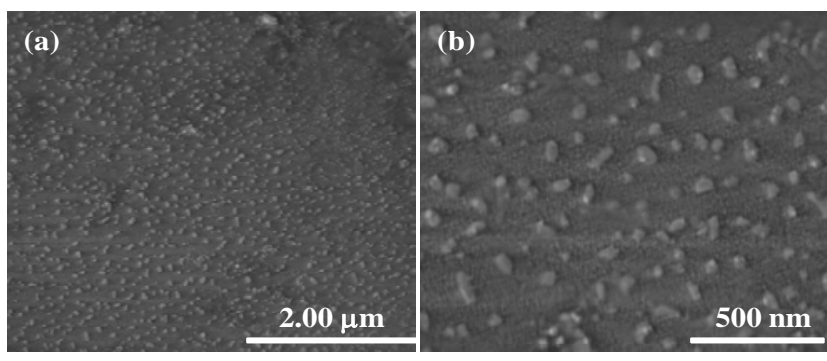

Fig. 3. Field emission scanning electron microscopy (SEM) images of NCNBs-800 under different magnification.

using FTIR; the spectrum is shown in Fig. 4. The peak at 3424 $\mathrm{cm}^{-1}$ can be assigned to $\mathrm{N}-\mathrm{H}$ stretching vibrations. The peaks at $2550,1661,1634$, and $700 \mathrm{~cm}^{-1}$ are assigned to the stretching vibrations of $\mathrm{C} \equiv \mathrm{N}, \mathrm{C}=\mathrm{N}, \mathrm{C}=\mathrm{C}$, and cis-olefin, respectively, suggesting elimination of $-\mathrm{OH}$ and $-\mathrm{NH}_{2}$ groups. The FTIR results suggest that nitrogen and carbon atoms with different degrees of saturation were formed during high-temperature Tris pyrolysis. The improved ORR performance is attributed to the electron-accepting ability of nitrogen atoms, which creates a net positive charge on adjacent carbon atoms in the NCNBs-800, enabling attraction of electrons and ORR facilitation $[39,40]$.

XPS was performed to determine the surface elements in the NCNB structure; the spectra are shown in Fig. 5. The XPS survey spectrum of the NCNBs-800 (Fig. 5(a)) shows narrow graphitic C $1 s(284.86 \mathrm{eV}), \mathrm{N} 1 s(399.82 \mathrm{eV})$, and $01 s$ (532.67 $\mathrm{eV}$ ) peaks, without any impurities, indicating the presence of a few oxygen-containing groups on the NCNBs-800, which will

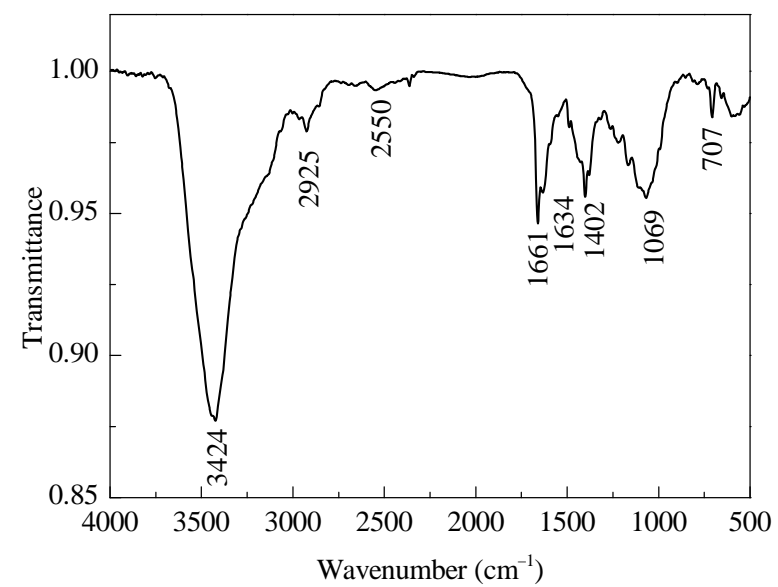

Fig. 4. FTIR spectrum of the NCNBs-800.

assist NCNBs-800 dispersion. The spectrum clearly indicates the presence of nitrogen in the NCNBs-800, indicating efficient nitrogen doping. The $\mathrm{C} 1 \mathrm{~s}$ peak for the NCNBs-800 is centered at approximately $284.6 \mathrm{eV}$, with a tail at higher binding energy, which is a common effect for nitrogen-doped carbon materials. The carbon species in the NCNBs-800 were further investigated based on the high-resolution $\mathrm{C} 1 \mathrm{~s}$ spectrum (Fig. 5(b)). The spectrum has peaks at 285.5, 289.3, 284.5, and $286.7 \mathrm{eV}$, which correspond to $\mathrm{C}=\mathrm{C}, \mathrm{C}-\mathrm{N}, \mathrm{C}-\mathrm{C}$, and $\mathrm{C}-\mathrm{O}$, respectively. The $\pi-\pi$ conjugated $\mathrm{C}=\mathrm{C}$ functional groups can accelerate electron transfer in the ORR. The N $1 s$ XPS spectrum of the NCNBs-800 can be deconvoluted into three peaks, centered at 398.3, 400.0, and $401.1 \mathrm{eV}$. The three individual peaks indicate the presence
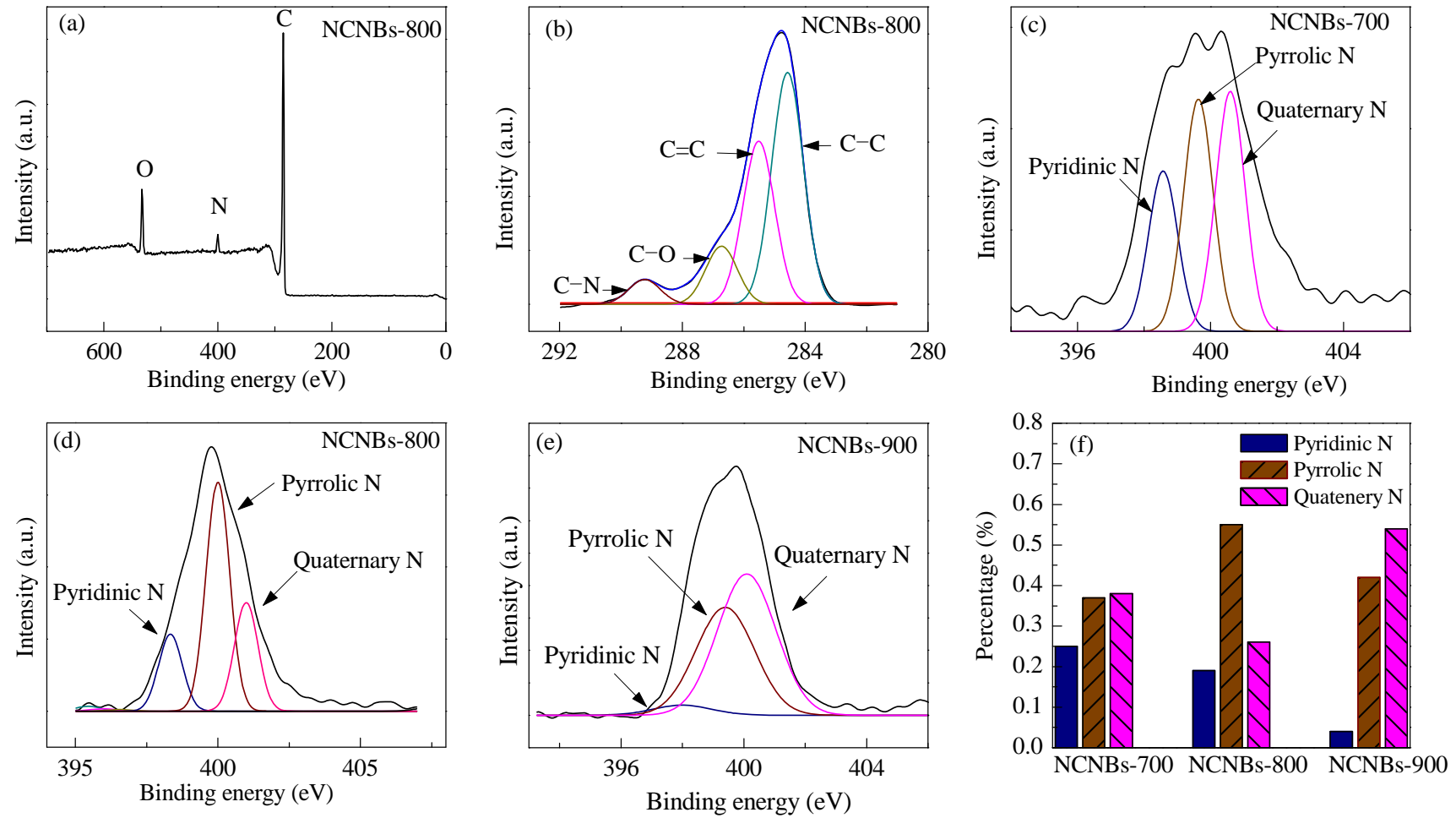

Fig. 5. (a) The wide XPS survey of NCNBs-800; (b) High-resolution C $1 s$ XPS spectra of NCNBs-800; (c, d, e) High-resolution N 1s XPS spectra of NCNBs at different pyrolysis temperatures ; (f) The percentage of three nitrogen species in NCNBs pyrolysed at different temperatures. 
of three types of nitrogen bonding. The peaks at 398.3 and $400.0 \mathrm{eV}$ are assigned to pyridinic and pyrrolic nitrogen, respectively, contributing one and two $\pi$ electrons, respectively, to the $\pi$-conjugated network. The peak at $401.1 \mathrm{eV}$ is assigned to quaternary nitrogen, indicating that nitrogen atoms replaced carbon atoms in the NCNBs-800. All these nitrogen atoms play important roles in the ORR catalytic activities of the carbon materials, especially the pyridinic and pyrrolic nitrogen. The reported positions of different nitrogen types differ widely for different studies, possibly because of different nitrogen environments. The ORR performance depends on the bonding configurations of the nitrogen atoms in carbon materials [4]. When the nitrogen lone-pair electrons are hybridized with $s p^{2}$ carbon atoms, they provide electrocatalytically active sites in the NCNBs-800. The peak areas change significantly depending on the pyrolysis temperature, which suggests that different numbers of nitrogen atoms with various bonding configurations were formed during pyrolysis at various temperatures. Fig. 5(f) shows the percentages of different types of nitrogen in the samples produced at different pyrolysis temperatures. For pyrolysis at $800{ }^{\circ} \mathrm{C}$, pyrrolic nitrogen is dominant, but the pyrrolic nitrogen contents at 700 and $900{ }^{\circ} \mathrm{C}$ are lower. The amount of quaternary nitrogen formed at $800{ }^{\circ} \mathrm{C}$ is lower than those formed at 700 and $900{ }^{\circ} \mathrm{C}$. These results imply that the pyrolysis temperature influences the ratios of pyridinic, pyrrolic, and quaternary nitrogen. It can promote the formation of pyrrolic nitrogen and suppress the generation of quaternary nitrogen; this is beneficial because nitrogen provides highly active sites for the ORR.

Electrochemical impedance spectra can show changes in the surface properties of a modified electrode. The diameter of the semicircle at higher frequencies corresponds to the electron transfer resistance, and diffusion corresponds to the linear portion at low frequencies. Fig. 6 shows that the resistance, including the series resistance and charge-transfer resistance, of the NCNBs-800 is comparable to that of the Pt/C electrocatalyst, but significantly lower than that of the bare GCE, indicating that the fabricated NCNBs-800 have good conductivity and superior electrocatalytic activity.

\subsection{Electrocatalytic activity of NCNBs-800 in ORR}

We performed LSV measurements using an RRDE in an $\mathrm{O}_{2}$-saturated electrolyte solution consisting of $\mathrm{KOH}(0.1 \mathrm{~mol} / \mathrm{L})$ $\mathrm{KOH}$ to gain further insights into the ORR activity of the NCNBs-800. Fig. 7(a) shows the LSV curves of the NCNB/GCE at various rotational speeds from 400 to $2025 \mathrm{r} / \mathrm{min}$. RRDE voltammograms were obtained at a disk electrode scanning rate of $5 \mathrm{mV} / \mathrm{s}$ and a constant ring potential of $0.5 \mathrm{~V}$, to oxidize the $\mathrm{HO}_{2}{ }^{-}$intermediate. The electron transfer number $n$ and $\mathrm{HO}_{2}-$ intermediate production percentage $\left(\mathrm{HO}_{2}^{-}(\%)\right)$ were determined as

$$
\begin{gathered}
n=\left(4 \times I_{\mathrm{d}}\right) /\left(I_{\mathrm{d}}+I_{\mathrm{r}} / \mathrm{N}\right) \\
\mathrm{HO}_{2}-(\%)=\left(200 \times I_{\mathrm{r}} / \mathrm{N}\right) /\left(I_{\mathrm{d}}+I_{\mathrm{r}} / \mathrm{N}\right)
\end{gathered}
$$

where $I_{\mathrm{d}}$ is the disk current, $I_{\mathrm{r}}$ is the ring current, and $N$ is the current collection efficiency of the Pt ring, which was determined to be 0.4 . The calculated $\mathrm{HO}_{2}{ }^{-}(\%)$ value for the

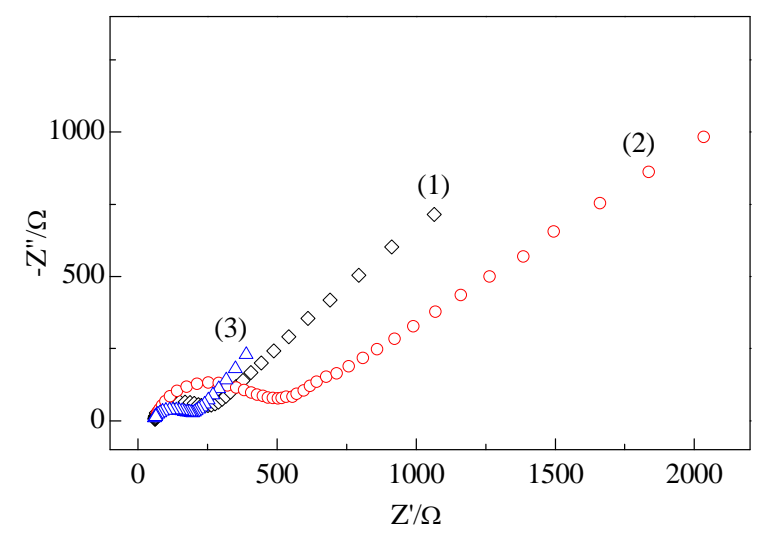

Fig. 6. EIS of (1) NCNBs-800/GCE, (2) bare GCE and (3) Pt/C/GCE in 0.1 $\mathrm{mol} / \mathrm{L} \mathrm{KCl}$ with $5.0 \mathrm{mmol} / \mathrm{L} \mathrm{K}_{3}\left[\mathrm{Fe}(\mathrm{CN})_{6} / \mathrm{K}_{4} \mathrm{Fe}(\mathrm{CN})_{6}\right]$.

NCNBs-800 is about $52 \%$ to $35 \%$ at potentials ranging from -0.3 to $-0.8 \mathrm{~V}$. The calculated $n$ value for the NCNBs-800 is about $3.0-3.4$ from -0.3 to $-0.8 \mathrm{~V}$. These results show that electrocatalysis of the ORR using the NCNBs-800 involves a simultaneous four-electron pathway and a two-electron transfer pathway. This excellent electrocatalytic activity shows that most of the doped nitrogen atoms are on the NCNBs-800 surface, especially the quaternary and pyridinic nitrogen, and oxygen molecules can be activated on both these types of doped nitrogen. Adjacent carbons transfer electrons to quaternary nitrogen atoms and the nitrogens donate electrons back to the adjacent $\mathrm{C} p_{z}$ orbitals. The donation and back-donation processes play an important role in the ORR by facilitating $\mathrm{O}_{2}$ dissociation on the adjacent carbon atoms, assisting formation of strong $\mathrm{O}-\mathrm{C}$ chemical bonds. Pyridinic nitrogen located on the NCNBs-800 surface can activate oxygen via direct bonding with the nitrogen lone-pair electrons; this promotes the ORR.

\subsection{Electrocatalytic stability of NCNBs-800 in ORR}

Long-term stability is a vitally important parameter for the ORR performance of a fuel cell. The durabilities of the NCNBs-800 and Pt/C catalysts in the ORR were tested using

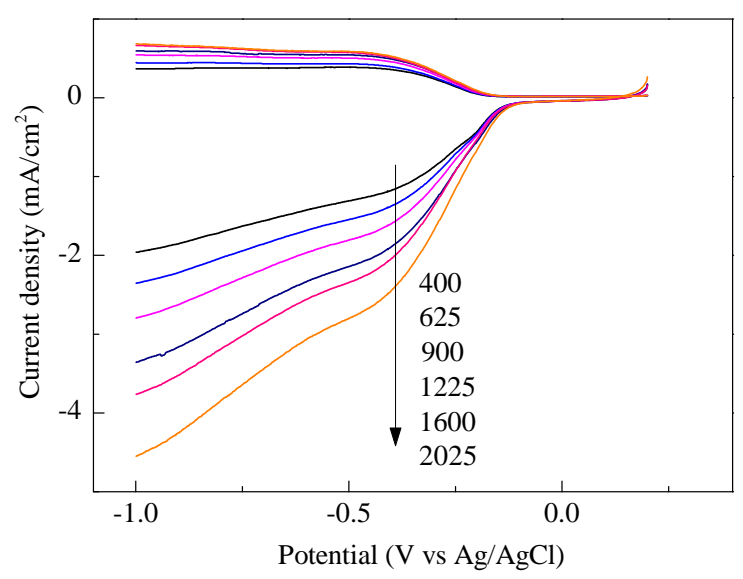

Fig. 7. RRDE LSV curves of ORR for NCNBs-800/GCE in the $\mathrm{O}_{2}$-saturated $\mathrm{KOH}$ solution $(0.1 \mathrm{~mol} / \mathrm{L})$ at a scan rate of $5 \mathrm{mV} / \mathrm{s}$ with different electrode rotation rate $(\mathrm{r} / \mathrm{min})$ and the Pt ring electrode was held at $1.2 \mathrm{~V}$. 


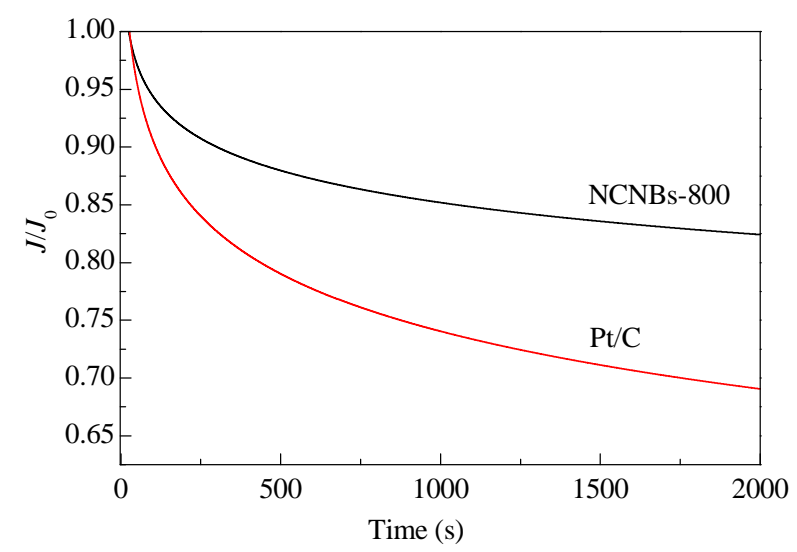

Fig. 8. Chronoamperometric responses of the NCNBs-800/GCE and the $\mathrm{Pt} / \mathrm{C}$ catalyst at $-0.2 \mathrm{~V}$ in the $\mathrm{O}_{2}$-saturated $\mathrm{KOH}(0.1 \mathrm{~mol} / \mathrm{L})$ electrolyte.

chronoamperometric measurements at $-0.2 \mathrm{~V}$; the stability curves of a commercial (20\%)Pt/C catalyst were also obtained under the same conditions for comparison. Fig. 8 shows that the current densities for both the NCNBs-800 and Pt/C electrodes initially decreased with time. However, the decrease for the NCNBs-800 electrode was much slower than that for the Pt/C electrode. After $2000 \mathrm{~s}$, the NCNBs-800 catalyst lost $17.56 \%$ of its initial catalytic activity; this is better than the performance of the commercial $\mathrm{Pt} / \mathrm{C}$ catalyst, which lost $30.71 \%$ of its initial catalytic activity. These results indicate that the NCNBs-800 prepared in this study are much more stable than a Pt/C catalyst in alkaline solution.

\section{Conclusions}

We have developed metal-free NCNBs with high nitrogen contents (4.11\%). They gave good electrocatalytic performance in ORRs. The NCNBs were fabricated using a scalable, one-step process involving Tris pyrolysis at $800{ }^{\circ} \mathrm{C}$. This synthetic method can be used to produce low-cost and scalable carbon-based and nitrogen-doped carbon materials. The ORR onset potential of the catalyst was $-0.05 \mathrm{~V}$ (vs $\mathrm{Ag} / \mathrm{AgCl}$ ) and the ORR reduction peak potential was $-0.20 \mathrm{~V}$ (vs $\mathrm{Ag} / \mathrm{AgCl}$ ). The NCNBs showed higher electrocatalytic activity, better long-term stability, and better tolerance of the methanol crossover effect compared with a commercial Pt/C ORR electrocatalyst. These results show that NCNBs prepared by pyrolysis of Tris as nitrogen and carbon sources at $800{ }^{\circ} \mathrm{C}$ provide a promising ORR catalyst for fuel cells.

\section{References}

[1] Y. F. Zhao, S. Q. Chen, B. Sun, D. W. Su, X. D. Huang, H. Liu, Y. M. Yan, K. N. Sun, G. X. Wang, Sci. Rep., 2015, 5, 1-11.

[2] J. Yan, H. Meng, W. D. Yu, X. L. Yuan, W. R. Lin, W. P. Ouyang, D. S. Yuan, Electrochim. Acta, 2014, 129, 196-202.

[3] D. Sebastián, V. Baglio, S. H. Sun, A. C. Tavares, A. S. Aricò, Chin. J Catal., 2015, 36, 484-489.

[4] L. Y. Feng, Y. Y. Yan, Y. G. Chen, L. J. Wang, Energy Environ. Sci., 2011, 4, 1892-1899.

[5] Y. X. Zhang, X. Guo, X. Zhai, Y. M. Yan, K. N. Sun, J. Mater. Chem. A, 2015, 3, 1761-1768.

[6] H. Wu, T. Peng, Z. K. Kou, J. Zhang, K. Cheng, D. P. He, M. Pan, S. C. Mu, Chin. J. Catal., 2015, 36, 490-495.

[7] L. H. Jiang, Q. W. Tang, J. Liu, G. Q. Sun, Chin. J. Catal., 2015, 36, 175-180.

[8] A. Q. Zhao, J. Masa, M. Muhler, W. Schuhmann, W. Xia, Electrochim. Acta, 2013, 98, 139-145.

[9] Z. Zou, H. Cheng, J. Y. Wang, X. J. Han, Chin. J. Catal., 2015, 36, 414-424.

[10] F. S. Saleh, T. Okajima, F. Kitamura, L.Q. Mao, T. Ohsaka, Electrochim. Acta, 2011, 56, 4916-4923.

[11] H. J. Zhang, H. L. Li, X. T. Li, B. Zhao, Z. F. Ma, J. H. Yang, Electrochim. Acta, 2014, 115, 1-9.

[12] M. Pattabi, R. H. Castellanos, R. Castillo, A. L. Ocampo, J. Moreira, P. J. Sebastian, Int. J. Hydrogen Energy, 2001, 26, 171-174.

[13] Q. Q. Xiao, Y. X. Zhang, X. Guo, L. Jing, Z. Y. Yang, Y. F. Xue, Y. M. Yan, K. N. Sun, Chem. Commun., 2014, 50, 13019-13022.

[14] D. S. Yu, Q. Zhang, L. M. Dai, J. Am. Chem. Soc, 2010, 132, 15127-15129.

[15] R. S. Zhong, Y. H. Qin, D. F. Niu, J. W. Tian, X. S. Zhang, X. G. Zhou, S. G. Sun, W. K. Yuan, J. Power Sources, 2013, 225, 192-199.

[16] J. S. Li, Y. Y. Chen, Y. J. Tang, S. L. Li, H. Q. Dong, K. Li, M. Han, Y. Q. Lan, J. C. Bao, Z. H. Dai, J. Mater. Chem. A, 2014, 2, 6316-6319.

[17] H. Jin, H. M. Zhang, H. X. Zhong, J. L. Zhang, Energy Environ. Sci., 2011, 4, 3389-3394.

[18] J. T. Zhang, Z. H. Zhao, Z. H. Xia, L. M. Dai, Nat Nanotechnol., 2015, $10,444-452$.

[19] Y. Q. Lin, K. Y. Liu, C. Y. Liu, L. Yin, Q. Kang, L. B. Li, B. Li, Electrochim. Acta, 2014, 133, 492-500.

\section{Graphical Abstract}

Chin. J. Catal., 2016, 37: 1275-1282 doi: 10.1016/S1872-2067(15)61123-8

Preparation of nitrogen-doped carbon nanoblocks with high electrocatalytic activity for oxygen reduction reaction in alkaline solution

Tingting Zhang, Chuansheng He, Linbo Li, Yuqing Lin * Capital Normal University

This study opens more opportunities for direct one-step pyrolysis technique to prepare nitrogen-doped carbon nanoblocks with excellent catalytic performance features which can be expected large-scale application for oxygen reduction reaction.

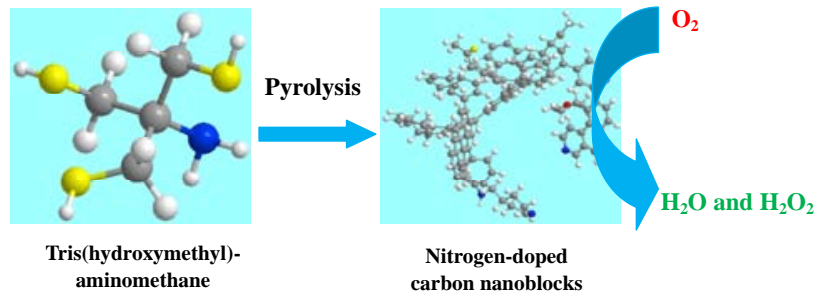


[20] L. B. Li, C. Wang, K. Y. Liu, Y. H. Wang, K. Liu, Y. Q. Lin, Anal. Chem., 2015, 87, 3404-3411.

[21] M. N. Zhang, K. Liu, L. Xiang, Y. Q. Lin, L. Su, L. Q. Mao, Anal. Chem., 2007, 79, 6559-6565.

[22] Y. Zheng, Y. Jiao, J. Chen, J. Liu, J. Liang, A. J. Du, W. M. Zhang, Z. H. Zhu, S. C. Smith, G. Q. Lu, S. Z. Qiao, M. Jaroniec, J. Am. Chem. Soc., 2011, 133, 20116-20119.

[23] Q. Q. Li, S. Zhang, L. M. Dai, L. S. Li, J. Am. Chem. Soc., 2012, 134, 18932-18935.

[24] Q. Liu, C. Y. Chen, F. P. Pan, J. Y. Zhang, Electrochim. Acta, 2015, 170, 234-241.

[25] S. B. Yang, X. L. Feng, X. C. Wang, K. Müllen, Angew. Chem. Int. Ed., 2011, 50, 5339-5343.

[26] L. T. Qu, Y. Liu, B. Baek, L. M. Dai, ACS Nano, 2010, 4, 1321-1326.

[27] K. P. Gong, F. Du, Z. H. Xia, M. Durstock, L. M. Dai, Science, 2009, 323, 760-764.

[28] W. J. Yuan, J. C. Li, A. J. Xie, P. Chen, S. K. Li, Y. H. Shen, Electrochim. Acta, 2015, 165, 29-35.

[29] K. Zhao, W. Gu, L. Y. Zhao, C. L. Zhang, W. D. Peng, Y. Z. Xian, Electrochim. Acta, 2015, 169, 142-149.

[30] Z. Y. Lin, G. H. Waller, Y. Liu, M. L. Liu, C. P. Wong, Carbon, 2013,
53, 130-136.

[31] H. W. Liang, W. Wei, Z. S. Wu, X. L. Feng, K. Müllen, J. Am. Chem. Soc., 2013, 135, 16002-16005.

[32] H. J. Yin, H. J. Tang, D. Wang, Y. Gao, Z. Y. Tang, ACS Nano, 2012, 6, 8288-8297.

[33] N. P. Subramanian, X. G. Li, V. Nallathambi, S. P. Kumaraguru, H. Colon-Mercado, G. Wu, J. W. Lee, B. N. Popov, J. Power Sources, 2009, 188, 38-44.

[34] Q. H. Guo, D. Zhao, S. W. Liu, S. L. Chen, M. Hanif, H. Q. Hou, Electrochim. Acta, 2014, 138, 318-324.

[35] T. Szabó, O. Berkesi, P. Forgó, K. Josepovits, Y. Sanakis, D. Petridis, I. Dékány, Chem. Mater., 2006, 18, 2740-2749.

[36] S. Chen, J. Y. Bi, Y. Zhao, L. J. Yang, C. Zhang, Y. W. Ma, Q. Wu, X. Z. Wang, Z. Hu, Adv. Mater., 2012, 24, 5593-5597.

[37] J. Lu, X. J. Bo, H. Wang, L. P. Guo, Electrochim. Acta, 2013, 108, $10-16$.

[38] R. Li, Z. D. Wei, X.L. Gou, ACS Catal., 2015, 5, 4133-4142.

[39] Y. Q. Sun, C. Li, G. Q. Shi, J. Mater. Chem., 2012, 22, 12810-12816.

[40] M. L. Liu, Y. F. Song, S. X. He, W. W. Tjiu, J. S. Pan, Y. Y. Xia, T. X. Liu, ACS Appl. Mater. Interfaces, 2014, 6, 4214-4222.

[41] S. Kang, P. K. Shen, Electrochim. Acta, 2014, 142, 182-186.

\title{
氮掺杂纳米碳块的制备及氧还原的高电化学催化活性
}

\author{
张亭亭，何传生，黎琳波，林雨青 ${ }^{*}$ \\ 首都师范大学化学系, 北京 100048
}

摘要: 面对全球化的能源危机, 燃料电池由于其高效性和可重复使用性成为越来越具有潜力的能量转化设备. 阴极发生的 氧气还原反应对于燃料电池的性能十分重要, 寻找高效的氧还原催化剂在很大程度上可以提高燃料电池的性能. 传统的 氧还原催化剂是贵金属铂, 但是铂的价格十分高, 较差的稳定性和选择性限制了它的商业化应用, 因此找到一种廉价高效 的非贵金属氧还原催化剂来代替铂基催化剂成为目前的研究热点.

我们最近发现将纯的三羟甲基氨基甲烷置于管式炉中在 $800{ }^{\circ} \mathrm{C}$ 下真空烧制 $2 \mathrm{~h}$, 可以简单快捷地得到一种含 $\mathrm{N}$ 量为 4.11\%的纳米碳块(标记为 NCNBs-800), 该材料可用于催化电化学氧气还原反应. 同样情况下在 700 和 $900{ }^{\circ} \mathrm{C}$ 下合成的材 料标记为 NCNBs-700 和 NCNBs-900. 采用傅里叶变换红外光谱 (FTIR)、X 射线光电子能谱 (XPS)、扫描电子显微镜 (SEM)、X 射线衍射 (XRD) 和电化学旋转圆盘方法与技术对催化剂的成分、形貌和电催化性能进行了表征.

SEM 表明 NCNBs-800 为直径为 $60 \mathrm{~nm}$ 的碳块, 用 FTIR 手段表征了 NCNBs-800 的结构变化, 三羟甲基氨基甲烷中的 $-\mathrm{OH}$ 和 $-\mathrm{NH}_{2}$ 在高温下发生消去反应, 形成了饱和度不同的 C $-\mathrm{N}$ 键和 C-C 键. 这些饱和度不同的 $\mathrm{N}$ 原子和 C 原子增加了 材料的缺陷结构和活性位点, 进一步促进了氧还原反应的催化性能. 采用 XPS 分析了 NCNBs-800 表面的元素, 通过对 N $1 \mathrm{~s}$ 进行分峰拟合, 发现 NCNBs-800 含有能促进氧还原性能的吡啶- $\mathrm{N}$ 和吡咯 $-\mathrm{N}$, 特别是吡啶- $\mathrm{N}$, 它吸电子的能力很强, 从而 导致与它邻近的 C 原子表面具有一定的正电荷, 这些正电荷促进了氧气的吸附和还原, 为氧气还原反应提供活性位点, 促 进氧气还原反应的发生. XRD 结果表明, 三羟甲基氨基甲烷热解前后的 XRD 谱图有明显变化, 热解后的三羟甲基氨基甲 烷呈现两个宽峰, 代表着杂化碳的存在. NCNBs-800 的衍射峰强度比 NCNBs-700 以及 NCNBs-900大, 但是宽度则比 NCNBs-700 以及 NCNBs-900 小, 这表明 $800{ }^{\circ} \mathrm{C}$ 有利于材料的石墨烯化及碳化过程.

电化学阻抗可以表明修饰电极的表面性质, 阻抗图中高频处半圆的直径大小代表电子转移阻力, 低频处的线性部分代 表扩散过程. 阻抗数据表明, NCNBs-800 的电荷转移电阻可与 Pt/C 催化剂相比, 但是比裸露的玻碳电极小. 这表明 NCNBs-800 有较好的导电性和电化学性质. CV 曲线表明 NCNBs-800 氧还原的起始电位是 $-0.05 \mathrm{~V}(\mathrm{vs} \mathrm{Ag/AgCl)}$, 氧气的 还原电位是 $0.20 \mathrm{~V}$ (vs Ag/AgCl), 说明 NCNBs-800 具有良好的电化学催化性能. 旋转环盘电极仪测得的氧还原极化曲线 表明, 在- 0.3 to $-0.8 \mathrm{~V}$ 下的 NCNBs-800 氧还原的电子转移数为 3.4, 过氧化氢产率为 $52 \%-35 \%$, 表明 NCNBs-800 呈现一 个提高的四电子过程.

稳定性对于燃料电池氧气还原反应也是一个十分重要的性能, 通过计时电流技术在电压为 $-0.2 \mathrm{~V}$ 下对 NCNBs-800 与 $\mathrm{Pt} / \mathrm{C}$ 进行了稳定性测试. 结果表明, 在 $2500 \mathrm{~s}$ 之后 NCNBs-800 相对于它的最初催化活性损失为 $17.56 \%$, 而 Pt/C 损失了 $30.71 \%$, 从而说明 NCNBs-800 的稳定性优于 Pt/C.

总之, 我们通过一步热解的简易技术制备了一种氮掺杂纳米碳材料, 该碳材料具有廉价、高效和容易制备等特点, 具有 
良好的电化学催化性能, 有望在燃料电池氧化还原反应中得到大规模应用.

关键词: 氮掺杂纳米碳块; 三羟甲基氨基甲烷; 电化学催化剂; 氧气还原反应; 纳米催化剂

收稿日期: 2016-01-04. 接受日期: 2016-04-29. 出版日期: 2016-08-05.

*通讯联系人. 电话: (010)68903047; 传真: (010)68903047; 电子信箱: linyuqing@cnu.edu.cn

基金来源：国家自然基金(21375088, 21575090); 北京市教育委员会科研计划(KM201410028006); 北京市市属高校青年拔尖人才 项目(CIT\&TCD201504072); 北京市教育委员会基础科学发展计划.

本文的英文电子版由Elsevier出版社在ScienceDirect上出版(http://www.sciencedirect.com/science/journal/18722067). 